\title{
DOI: 10.7596/taksad.v9i1.2354
}

Citation: Kirichenko, E., Punhina, O., \& Malezhyk, Y. (2020). Searching for Plastic Expressiveness in Alexander Osmerkin's Paintings: From "Cezannism" to "Silent Realism". Journal of History Culture and Art Research, 9(1), 209-224. doi:http://dx.doi.org/10.7596/taksad.v9i1.2354

\section{Searching for Plastic Expressiveness in Alexander Osmerkin's Paintings: From "Cezannism" to "Silent Realism"}

\author{
Elena Kirichenko', Olha Punhina², Yuliia Malezhyk ${ }^{3}$
}

\begin{abstract}
The article discusses the specifics of understanding the plastic expressiveness of painting by A. Osmerkin, which manifested itself differently at different stages of the artist's creative biography, determined by the sociocultural context of the 1920s - 1940s. The study revealed the aesthetic positions of the artist at an early and mature stage of creativity, reflecting priorities in the search for the plastic expressiveness of the painting. The figurative and stylistic features of his works created in different decades are considered; a comprehensive analysis of his aesthetic views and their reflection in the author's picture of the world has been performed. In addition, the authors introduce into the scientific circulation the artist's works from the museums of the Kropyvnytsky city, which were not previously considered in existing publications on the work of A. Osmerkin. The results of the study led to the conclusion that the artist paid great attention to the plasticity of color, with the help of which he built form and space, without taking the color composition from the task of the image. It was not the colorfulness itself that attracted spectators to the artist's paintings, but precisely the harmoniously constructed color that conveys the beauty of nature in its individual state through the color ratio. In the post-revolutionary time, A. Osmerkin became a consistent realist, working in chamber genres, he was interested not so much in the plot as in solving plastic problems by means of impressionistic painting. At this stage, the artist strives for pictures in the most "nonpainting" genres - in still life, landscape, portrait, working in a peculiar style of "quiet realism". Lyristic imagery of Osmerkin's paintings puts him among the artists who poetically reflect the world.
\end{abstract}

Keywords: Plasticity of painting, Russian avant-garde, Cezannism, "Quiet" realism, Coloristic expressiveness.

\footnotetext{
1 Ph.D., Associate Professor of the Department of Fine Arts and Design, Volodymyr Vynnychenko Central Ukrainian State Pedagogical University, Kropyvnytskyi, Ukraine. olivki777@gmail.com

2 Ph.D., Associate Professor of the Department of Fine Arts and Design, Volodymyr Vynnychenko Central Ukrainian State Pedagogical University, Kropyvnytskyi, Ukraine.pyngina@i.ua

${ }^{3}$ Ph.D., Senior Lecturer at the Department of Fine Arts and Design, Volodymyr Vynnychenko Central Ukrainian State Pedagogical University, Kropyvnytskyi, Ukraine. 28julimal@gmail.com
} 


\section{Introduction}

The latest trends in European art of the first third of the 20th century vainly sought to radical changes in the system of artistic expressiveness. Ultimately, the search for this expressiveness was radically reduced to an understanding of the plasticity of the pictorial image. Similar searches took place in the Russian art, but they were forcibly interrupted with a violent change in the socio-political system in the country, which affected the artistic ideals of the new era. In the 1930s, many masters of painting were already forced to leave the search for avant-garde. At the USSR an active struggle has been waged against the so-called "formalism", where all the trends of the Russian avant-garde were attributed. But the appeal to well-recognized academic forms did not prevent any artists from the search for plastic expressiveness of painting, they repeatedly tried to revive the pictorial language of their canvases and turned to the problems of picturesqueness, leaving aside the ideological component. As a result of this critical stance, these artists had been targeted by the official criticism.

That turned out to be the way of Alexander Osmerkin, who at initial stage was drawn to P. Cézanne, later - to the French romantics, barbizons and impressionists, also Russian artists of the 19th century realistic school fell into the sphere of his interests. In all periods of his creative work, A. Osmerkin sought to preserve the painterly principles and high professional culture, thus he hasn't become a "Soviet" artist in that sense, which was required by a new ideology, although he attempted to create pictures that met the requirements of modernity. These attempts to take the leap like this proved to be painful and were not accepted or approved by the authorities. And the desire to preserve the loyalty to true pure painting turned into a great life tragedy for the artist.

Among those masters of the "Jack of Diamonds", who managed to enrich their own pictorial style with techniques of other artistic systems, Alexander Osmerkin, perhaps, stands out more than others. His creative life was accompanied by a tireless search for an individual artistic style. Such genres as still life, landscape and portrait dominate in the artist's work, but almost all genre motifs introduce additional - lyrical - intonations. The main peculiarity of the artist's searches was the desire for the synthesis of various art systems through a special, individual understanding of such a category as plastic art. Considering the paintings of A. Osmerkin in the context of his understanding of the pictorial artwork, we will be able to comprehend and appreciate his contribution to the art of the twentieth century and his concept of updating the imagery as part of a synthesis of artistic traditions.

Alexander Osmerkin is an artist whose name in art criticism is associated with the creative pursuit of the Jack of Diamonds association. At the same time, those who mention him in the context of Russian Cezannism write about him without any details, noting the influence of the Cezanne's manner on his early-period paintings. Further searches and discoveries of A. Osmerkin in painting were practically not considered in full. Meanwhile, he is one of those creators who, in the difficult sociocultural conditions that prevailed during the stalin period, managed to find ways to preserve the purity of painting conceptions. The artist's attention was directed to those problems that did not seem relevant during the reign of Soviet ideology. He developed the picturesque discoveries that took place in the 19th - first half of the 20th century, finding new nuances for both his painting and the creativity of his students. The problem of the influence of the A. Osmerkin's painting system on the new generation of artists was practically not addressed by the researchers, the same as the artist's own achievements in the post-Cezanne period were not considered.

There are not many publications dedicated to the work of A. Osmerkin. Almost a decade and a half after the death of the artist in 1953, his legacy remained almost unknown to the wide audience. The 
earliest information about him in special publications dates back to 1939-1940s, when E. Melikadze and P. Syisoev dedicated a small essay to the artist in the collection "Soviet Painting" (Melikadze \& Syisoev, 1939); and in 1940 a group exhibition with A. Osmerkin's participance was held and as a resulted in a publication of a catalog (Malkova, 2006; Morozov, 1995). Postmortem exhibitions organized on the initiative of the master's widow, demonstrated the importance of the artist's personality and the uniqueness of his painting system, and also prompted him to write research articles about him and to publish books about his work. Small articles by A. Deyneka and L. Akimova appeared on the pages of the journals "Creativity" and "Art" in 1959 and 1960, being a kind of representation of the master's creative path (Deyneka, 1959; Akimova, 1960). Then, in connection with the 20th anniversary of the death of A. Osmerkin, art journals published memories of his student A. Nikich about his teacher (Nikich, 1981). A small book by L. Usoltseva, published in 1978 in the popular series "The Mass Library of Art", on 12 pages of the text of which the reader is offered an introductory text about the artist's work, accompanied by low-quality illustrations should be mentioned among independent publications (Usoltseva, 1978). The author of this publication did not set out to deeply analyze the milestones of creativity and the search for the pictorial expressiveness of A. Osmerkin. The "Reflections on Art. Letters. Criticism. Memoirs of Contemporaries" was published in 1981 - the only substantial source that allows to get an idea of the personality and the artistic as well as aesthetic position of the master. The publication already included Nikich's wellknown memoirs, as well as new testimonies of A. Osmerkin's contemporaries about him (Nikich, 1981). The main value of the book was the letters published there, the master's autobiography and the chronology of his creative life. Finally, in the late 1980s, two catalogs of personal exhibitions of the artist appeared, which housed the same article by I. Bolotina and A. Shcherbakov, previously published in the specified edition of Reflections .... (Bolotina \& Shcherbakov, 1989). When in the city of Kirovograd (now Kropyvnytskyi) in Ukraine, where A. Osmerkin came from, his art and memorial museum was created, some aspects of the painter's work were examined by A. Nadezhdin, a museum employee. However, even up to present days there is no monograph covering in its entirety the creative path and various problems of the Osmerkin's creative searches; there was no understanding of the master's creative heritage with all its complexities, contradictions, discoveries, his picturesque concept and his contribution to artistic pedagogy haven't been appreciated as well (Nadezhdin, 2004, 2007).

The purpose of this article is to examine the specifics of understanding the plastic expressiveness of painting in the work of Alexander Osmerkin, which manifested itself differently at different stages of the artist's creative biography, determined by the sociocultural context of the 1920s $-1940 \mathrm{~s}$. In connection with the goal, it is proposed to solve the following problems:

- identification of the aesthetic positions of the artist at an early and mature stage of creativity, reflecting priorities in the search for the plastic expressiveness of the painting;

- consideration of the figurative and stylistic features of the artist's works at different periods of creativity;

- A comprehensive analysis of Osmerkin's aesthetic views and their reflection in his picture of the world;

- Introduction to the scientific archive of the artist's works from the museums of Kropyvnytsky, that were not previously considered in existing publications on the work of A. Osmerkin. 


\section{Methodology}

The source of the study was the artist's letters, memories of him, theoretical understanding of his work by some researchers, the works themselves, which are stored in various museum collections, primarily in museum collections in Kropyvnytsky. The methodological base is based on theoretical methods based on a systematic approach that allows us to consider the painting system of $A$. Osmerkin in conjunction with the cultural context. The art-cultural approach has defined scientific methods that allowed to explore the artist's creative searches in the context of the development of the latest pictorial searches, caused by sociocultural changes at different periods. A holistic perception of the artist's works is provided by art criticism methods based on a figurative-stylistic analysis of the works, including philosophical and aesthetic methods based on the concepts of T. Adorno, H. Gadamer, M. Kagan and others (Adorno, 1995; Gadamer, 1960; Kagan, 1997). The comprehension of the ontological and phenomenological nature of the artist's creative work made it possible to develop theoretical principles that lead to an understanding of the multidimensionality and ambiguity of the object of artistic analysis. In this study, we also relied on a sociological analysis, which is based on the study of the problems of organizing artistic life, as well as on formal-analytical methods, through which the problems of poetics and shaping in the artist's works were considered.

\section{Background}

Until recently, a consideration of the plastic expressiveness of painting in art history hasn't been a priority. This problem was identified in 2015, at the Inter-Institute Seminar of Art Critics in Moscow, "The Nature of Plastic Sense. Classical understanding and metamorphoses." In some scientific reports of the seminar, attention was also paid to the plasticity of painting, a category most often used for plastic art forms. The publications and studies of O. Krivtsun (2018), O. Malkova (2006) allow us to look from a different point of view at the problems of the plastic expressiveness of painting and discover how this category explains the author's pictorial concepts of the 20th century. A significant number of recent studies on the nature of the discoveries of the "Jack of Diamonds" representatives, art association makes it possible to discover some problematic aspects of A. Osmerkin's creativity not only in his Cezannist period, but also in the later stages of painting searches. At the same time, it should be mentioned that all the authors - G. Pospelov (1990), A. Kostenevich (1998), O. Malkova (2006), K. Svetlyakov (2002), E. Turchinskaya (2013) - ignored A. Osmerkin as an active "jack-ofdiamonds man", sometimes mentioning his participation in some exhibitions. The more significant and vivid figures that were at the base of this association seemed to overshadow those who joined it later. However, in our opinion, such injustice should be eliminated; it most likely arose due to the departure of A. Osmerkin from Cezannism, which happened to all participants "Jack of diamonds" during the Soviet period. In addition, a new understanding of the artist's personality and its role in the development of the art of the Soviet period is necessary, in which A. Osmerkin took a very special place, which has not been revised since the publications mentioned above.

\section{Results}

The creative biography of A. Osmerkin begins in the city of Elisavetgrad (now Kropyvnytskyi), where he was born in 1892. In Elisavetgrad, his uncle, his mother's brother, the famous architect Yakov Pauchenko, had a great impact on the young artist. Yakov Pauchenko had a creative atmosphere in his house, and young A. Osmerkin was a regular participant of home theater performances and even dreamt of becoming an actor. Having decided to paint, A. Osmerkin enters the evening drawing classes of the Elisavetgrad county school, which was led by Theodosius Kozachinsky, the wanderer artist from St. Petersburg. The first fundamental principles of the creative process were perceived at his lectures. 
After the lessons of the visual literacy, the eighteen-year-old A. Osmerkin decided to continue his studies in St. Petersburg, and in 1910 he entered the studio of Nicholas Roerich, that belonged to the Imperial Society for the Encouragement of the Arts at the Academy of Fine Arts, but disappointment made him to return to Ukraine soon. In 1911 he entered the Kiev Art School, however, here, according to his own recollections, the same "half-handicraft academicism, that extinguished passion" expected him (Nikich, 1981: 40). A. Osmerkin was looking for a more modern and energetic language in art. After the exhibition of the popular artists in Kiev (and perhaps even in St. Petersburg), where A. Osmerkin, he claims, first saw the paintings of the "Jack of Diamonds" participants, he finally strengthened his plans to leave Kiev. Shortly he moved to Moscow and went to private studio of llya Mashkov, one of the founders of the "Jack of Diamonds" (Painting 1).

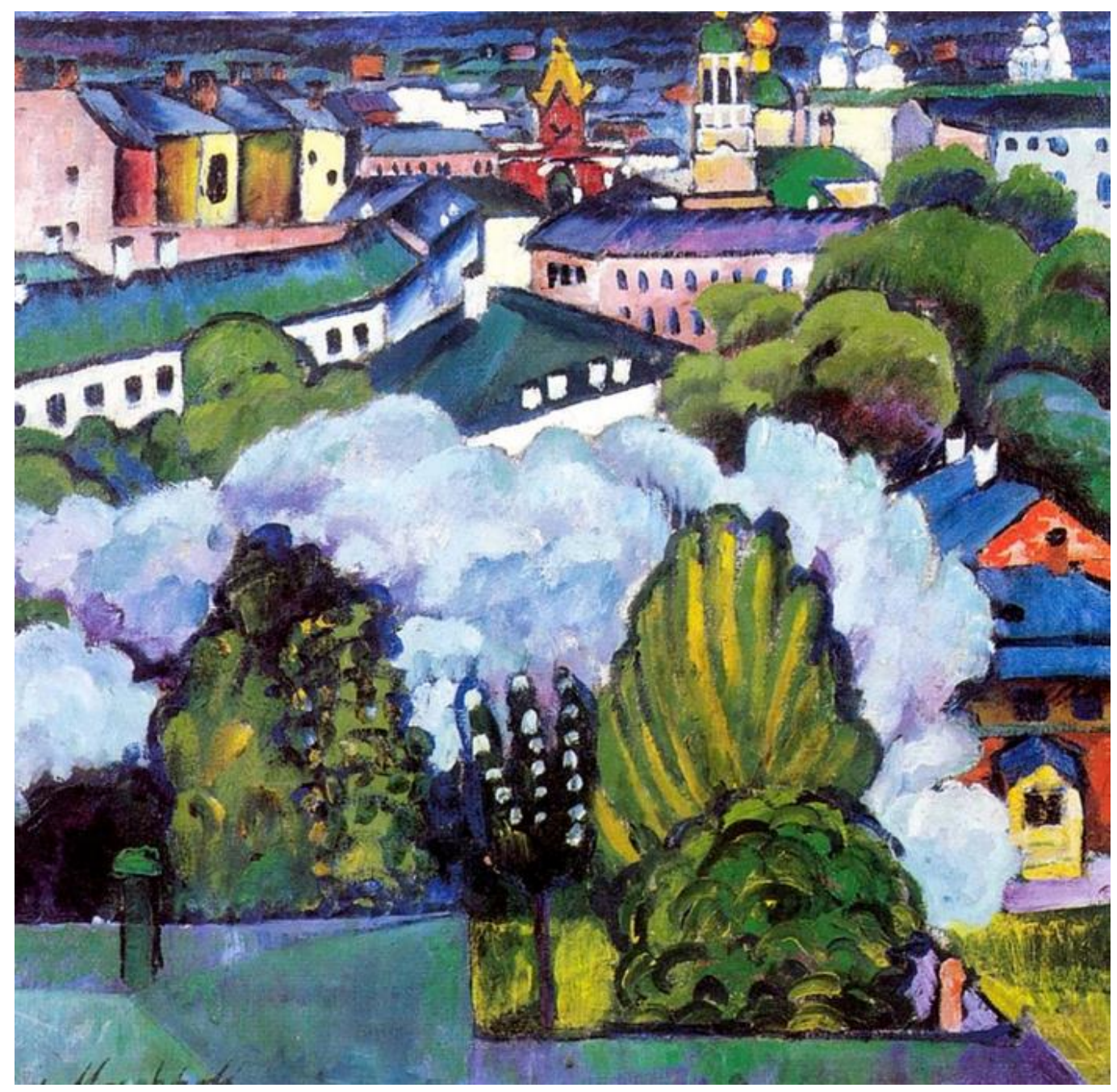

Painting 1: Ilya Mashkov, City landscape, 1911, oil on canvas, $93 \times 96 \mathrm{~cm}$. State Russian Museum, St. Petersburg (photograph from open sources).

The classes in that studio and the artistic environment that the young artist soon got into, and since 1918 - he was working together with P. Konchalovsky, who also stood at the origins of the "Jack of Diamonds" (Nikich, 1981: 40) - all of these contributed to the formation of artistic preferences of the beginner painter (Painting 2). The whole period of his participation in the artistic union, he prefers juicy, "tasty" painting, enjoys the works of P. Cézanne and the cubists Cezanne's trace in Russian art is rethought after a large exhibition "Paul Cézanne and the Russian avant-garde of the early XX century", which took place in 1998 in Moscow and where the largest Russian museums were involved along with the foreign museum collections (Kostenevich, 1998). This exhibition attracted attention to many problems that were not fully revealed in contemporary art history and several dissertations 
appeared at once at the turn of the XX - XXI centuries, where the authors considered the ways of forming avant-garde trends in Russian art. So Kirill Svetliakov in his dissertation notes that "the groups of Malevich and the masters of the "Jack of Diamonds" can be qualified as schools of painting that emerged based on the experience of Cézanne. These schools were unique not only for Russia, but for the whole "Cézanne's" XX century" (Svetlyakov, 2002). K. Svetliakov emphasizes, that Russian avant-garde artists, above all, found it close and understandable that P. Cézanne came to the liberation of pictorial information from verbal, narrative qualities, therefore color plasticity dominates in his painting: feelings that are transmitted by color scales develop into quality of pictorial structure. This "value of direct sensation" is the main condition for the "plastic value of the picture (with the whole complex of so-called formal qualities)" (Svetlyakov, 2002: 16). That means that P. Cézanne coordinates the process of direct perception as much as possible with the process of thinking and "this task includes the experience of natural vision, the experience of plastic analysis and the conceptual experience of statement" (Svetlyakov, 2002: 18).



Painting 2: Pyotr Konchalovsky, Begonias, 1911, oil on canvas, $93 \times 107 \mathrm{~cm}$. State Russian Museum, St. Petersburg (photograph from open sources).

Many contemporary Russian researchers write about the significance of P. Cézanne's pictorial reform for the Russian artists, who focused on the avant-garde artists' intuitive understanding of the "primeval power" of Cézanne's plastic system. The artists of the "Jack of Diamonds" turned out to be close to the main method of P. Cézanne, which G. Pospelov called the "method of pictorial analysis" (Pospelov, 1990: 130). Thus, the phenomenon of objective generalization of the world and the identification of its plastic homogeneity, which is present in every Cézanne's artwork, became the main visual device among the masters of the "Jack of Diamonds". Thus, the search directions in the transformation of the artistic painting language by russian supporters of P. Cézanne largely coincided with the general search for Russian avant-garde art, which significantly accelerated its overall development. Those pictorial techniques that were created by artists in the period of a radical search for something new, repeatedly became a model for the younger generations of the future artists.

The essence of the concept of "plastic expressiveness" of painting should be defined; and it should be revealed what exactly attracted the masters of avant-garde trends in their desire to update the language of the visual arts precisely in the aspect of this concept. By "plastic expressiveness" the method of creating artistic imagery is meant, with the help of which the plastic idea of the work will be expressed. Plasticity is an important characteristic of any artistic image, the structure of which provides the reflection of abstract content in a concrete, sensual form. Therefore, actually, plastic expressiveness of painting is understood as such ways of creating figurative in which the pictorial component is especially emphasized by the artist with the help of color, color scale, form and 
methods of painting modeling. Oleg Krivtsun, a researcher of the plasticity problem in the visual arts, speaks of "plastic thinking in the material", which for a painter is defined as "working with the texture of an oil canvas, adding his visuality through lines of drawing, spots, volume ratios, color and light" (Krivtsun, 2018). In connection with the disclosure of "plastic expressiveness" concept, the term "plastic image" is also actualized, which can be correlated with a number of other terminological definitions - picturesqueness, pictoriality, materiality, density of the artistic image. Plastic sense can be defined as the ability to experience the pleasure of perception of the integrity and unity of the painterly form. It is born as a reaction to the expressiveness of the artistic language. Therefore, artists of the early 20th century, who especially appreciated the expressiveness of color and shape, could not remain within the framework of the traditional classical understanding of these categories and were concerned about the search for such techniques that would form a new plastic thinking.

Paintings A. Osmerkin of the 1910s - early 1920s are built on the basis of a rethinking of Cézanne's plasticity, which, for example, can be clearly seen in the early artist's works from the collection of the A. Osmerkin Art-Memorial Museum in Kropyvnytskyi [hereinafter: Osmerkin Museum]: "The neighborhood of Elisavetgrad" $(20 \times 4,5)$, "Distillery in Elisavetgrad" $(19 \times 30,5)$ (both 1910-1911, oil on canvas), "House with columns" (Painting 3). A. Osmerkin writes with broad strokes, ocher and emerald tones dominated in his palette; mobility and color saturation created the shape of the object and visually enhanced the dynamism of the composition itself.

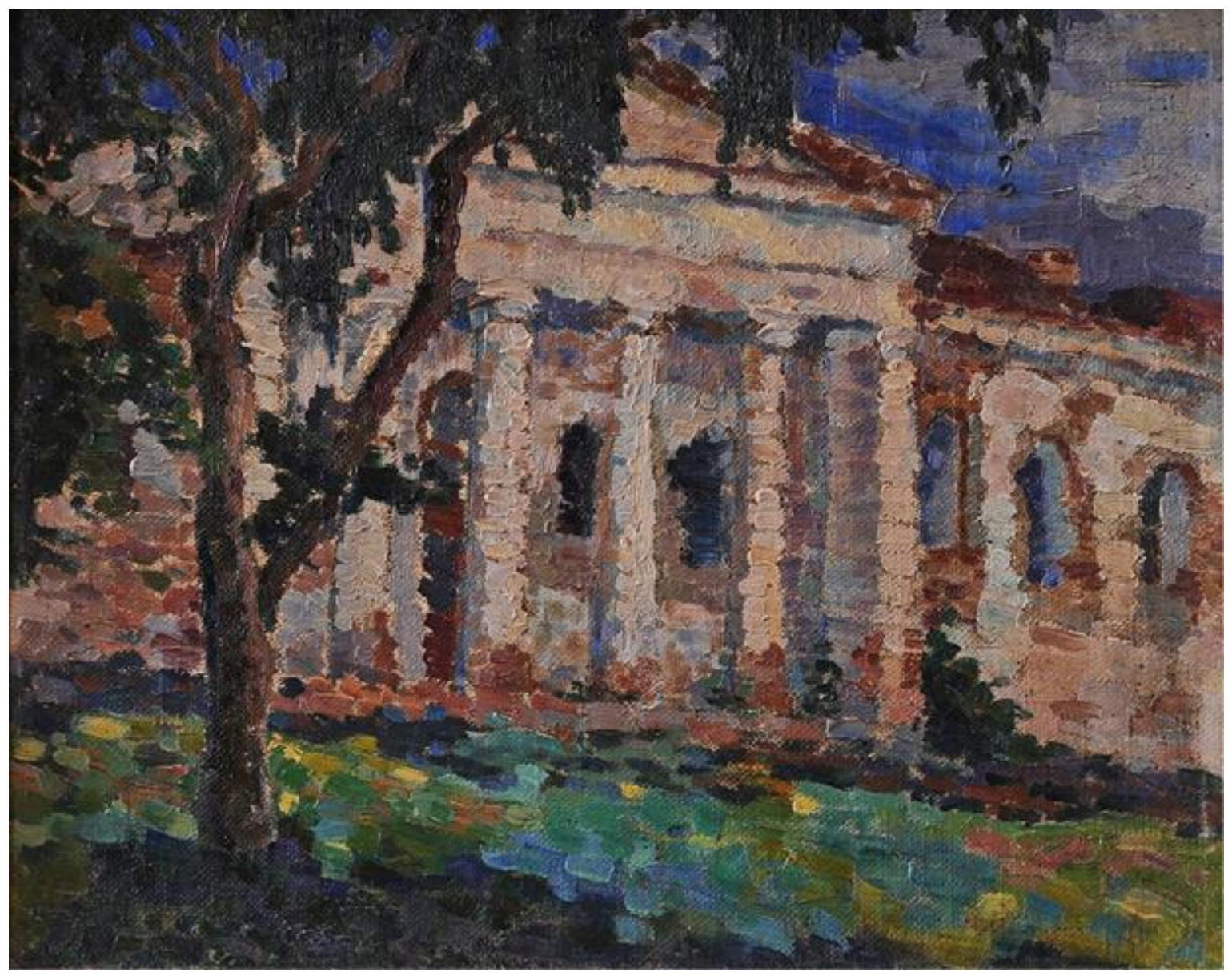

Painting 3: Alexander Osmerkin's, House with columns, 1911, oil on canvas, $31 \times 37 \mathrm{~cm}$. A. Osmerkin Art-Memorial Museum, Kropyvnytskyi (photograph provided by Osmerkin Museum, № XMMO-126). 
From the first steps, the artist attaches great importance to working with color, which is devoid of screaming activity, but rather has the property of synthesizing things and space; and not only conveys materiality and the texture of things, but also combines them into a single action with the background, creating such a world, where items are endowed with increased pictorial plasticity. Thus, the objects depicted seem to receive new qualities that increase their intrinsic value. The artistry with which the early works were performed and the mastery of tonal development distinguish the style of the young painter and have put him in common row with those, who have already won some socialist recognition. The leading principle of A. Osmerkin's canvases in the period of 1910s - 1920s was precisely the color dynamics and pictorial plasticity, and this dynamics was evenly distributed in the space of the canvas: active color movement seems to dismember the forms into light color spots, the pictorial rhythms alternate with varying degrees of density and concentration of the saturated form in the center, and then disperse throughout the canvas. At the same time A. Osmerkin tries not to go very far from the direct perception of life in his pictures, which is his would-be feature, such are the "Self-portrait" (Painting 4), "Lady with Lorgnette (Portrait of a Lady with a Poster)" (1917; oil on canvas, $116 \times 91$; the State Russian Museum, St. Petersburg), "Still Life with a Clock" (1920; oil on canvas, $89 \times 50$; State Museum of Fine Arts, Republic of Tatarstan, Kazan), "In the cafe (Ekaterina Timofeevna Barkova)" (1919; oil on canvas, 140,5 × 106; the State Tretyakov Gallery, Moscow [hereinafter: the Tretyakov Gallery]).

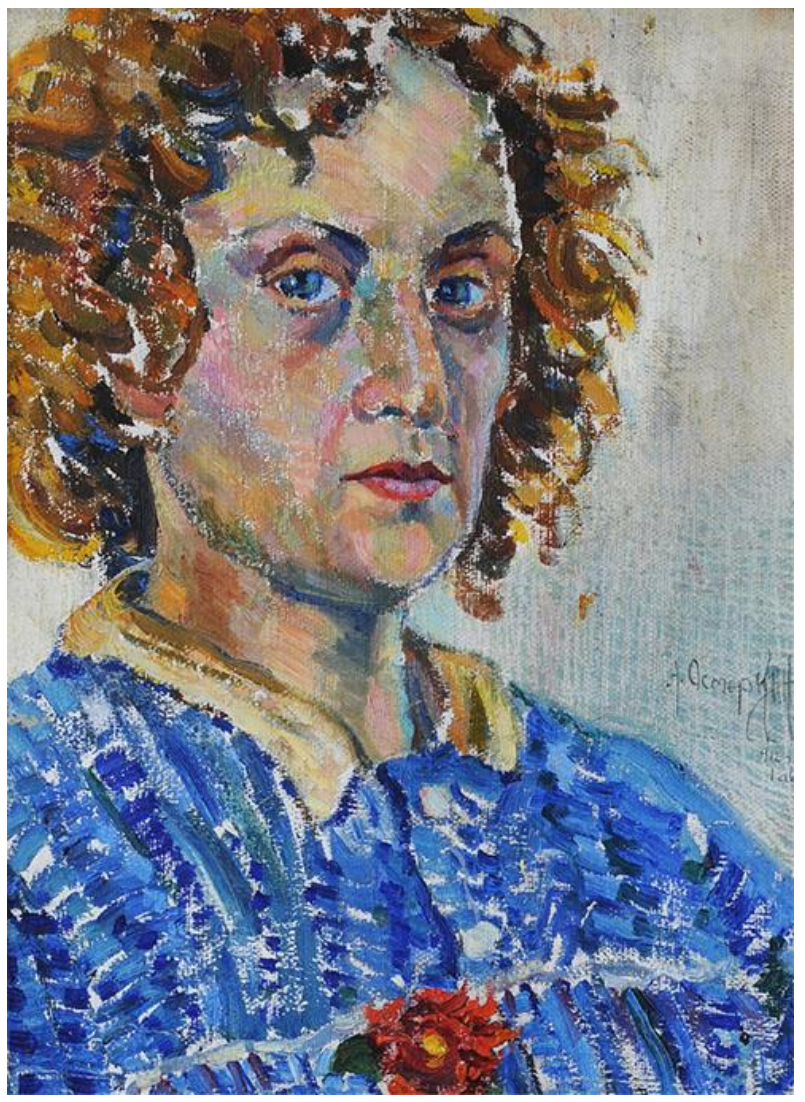

Painting 4: Alexander Osmerkin's, Self-portrait, 1912, oil on canvas, $41,5 \times 33 \mathrm{~cm}$. A. Osmerkin ArtMemorial Museum, Kropyvnytskyi (photograph provided by Osmerkin Museum, № XMMO-1130).

In the paintings of that period, such unique features as: appeals to the stylistics of postimpressionism, Fauvism and Cubism, a cubistic understanding of space and object, the ability to organize a composition, to "hold" the plane of the entire canvas, as well as a restrained palette that is close to one tonality are distinctly palpable. In "The Sleeping Woman and Dog" (1925, oil on 
canvas; $103 \times 142$; Osmerkin Museum), the same Cézanne's molding of the form is felt in the naked body of a sleeping woman, in the image of the bed, in the background and drapery.

In the 1920 s - 1930s, changes in the work of A. Osmerkin took place in a general direction: starting from the enthusiasm of the Cézanne's plastic modeling of the form and the pictorial space, he would gradually change his writing style and attitude to radical innovations of the pictorial language. However, he was the one to synthesize a variety of pictorial sources in his work.

During the 1920s, a decisive shift towards realism was already apparent in the art of A. Osmerkin. The artist was not original in this - similar changes occurred in the style of other participants of the "Jack of Diamonds." A. Osmerkin seems to be rediscovering Rembrandt Harmenszoon van Rijn, artists of Romanticism, Barbizonians, Gustave Courbet, Russian masters of realistic painting of the XIX century, he is attracted by the previously disputed plot in painting. From the mid-1920s, the works of A. Osmerkin are quite realistic. At the same time, the former role of color in the picture is preserved. In the landscape works of this period, the green of trees sounds fully and powerful, the depicting of the tree trunks' elasticity and strength is astounding, space is built using constructively arranged and coloristically highlighted plans: "Botanical Garden" (1924; oil on canvas, $90 \times 69$; regional Art Museum, Kropyvnytsky [hereinafter: the Regional Art Museum]), "Svyatogorsky Monastery" (1928; oil on canvas, $74 \times 95$; same place). The principle, that was almost sacred to any cezannist: "painting is the right color on the right place" remains unchanged, but at the same time the artist is interested in the transfer of the objects' textures in still life, to psychology in a portrait, to recreation of the lyrical mood in a landscape.

To summarise, the first independent steps in the artwork, Alexander Osmerkin has been taking on the wave of a strong passion for P. Cézanne, has found adherents in the creative association "The Jack of Diamonds" and, having much in common with the artistic and aesthetic concepts of representatives of it, stood out from them to synthesize different art systems in painting. The plasticity of color in the artist's works is of significant importance, and always plays the key role in formation of space and shape. The art of the 1930s, represented by the names of I. Mashkov, P. Konchalovsky, A. Kuprin, A. Lentulov, A. Osmerkin, continues the development of trends that emerged in the 1920s. The usage of realistic techniques is complemented by the impressionistic ones and is painted with greater emotionality. Some authors, writing about the artistic situation of that time, even state a gradual decrease of the volitional beginning and energy in the works of the former representatives of the "Jack of Diamonds". Loss of scale, clarity and certainty of the idea should also be mentioned.

The period of the 1930s - 1940s turned out to be ambiguous in A. Osmerkin's creative biography. It was the time of the socialist realism canons approval, when every artist had to sing through the beautiful life of the Soviet country. Alexander Morozov in the monograph "The End of Utopia" dwells on the analysis of the key myths of the era, on considering the specifics of creating the image of the "new man" in the art of socialist realism, stressing that the regime and the artists serving it needed a "sea of people smilingly waving under the leader's shoes" people "with patriotic readiness in the eyes and with flowers in their hands" (Morozov, 1995). A. Osmerkin could not be included in this bacchanalia of "universal happiness", it just disgusted his nature. He tries to step aside, choosing neutral genres for himself.

During these years the artist is primarily interested in the still life genre. In the canvas from the Regional Art Museum "Ukraine" (Painting 5) and a sketch for it from the Osmerkin Museum (1926; oil on canvas, $64 \times 55,5)$, created during one of the visits to his homeland and performed in the Cézanne's style, one can feel the consonance with some panoramic views of Mount Saint-Victoire by P. Cézanne. 


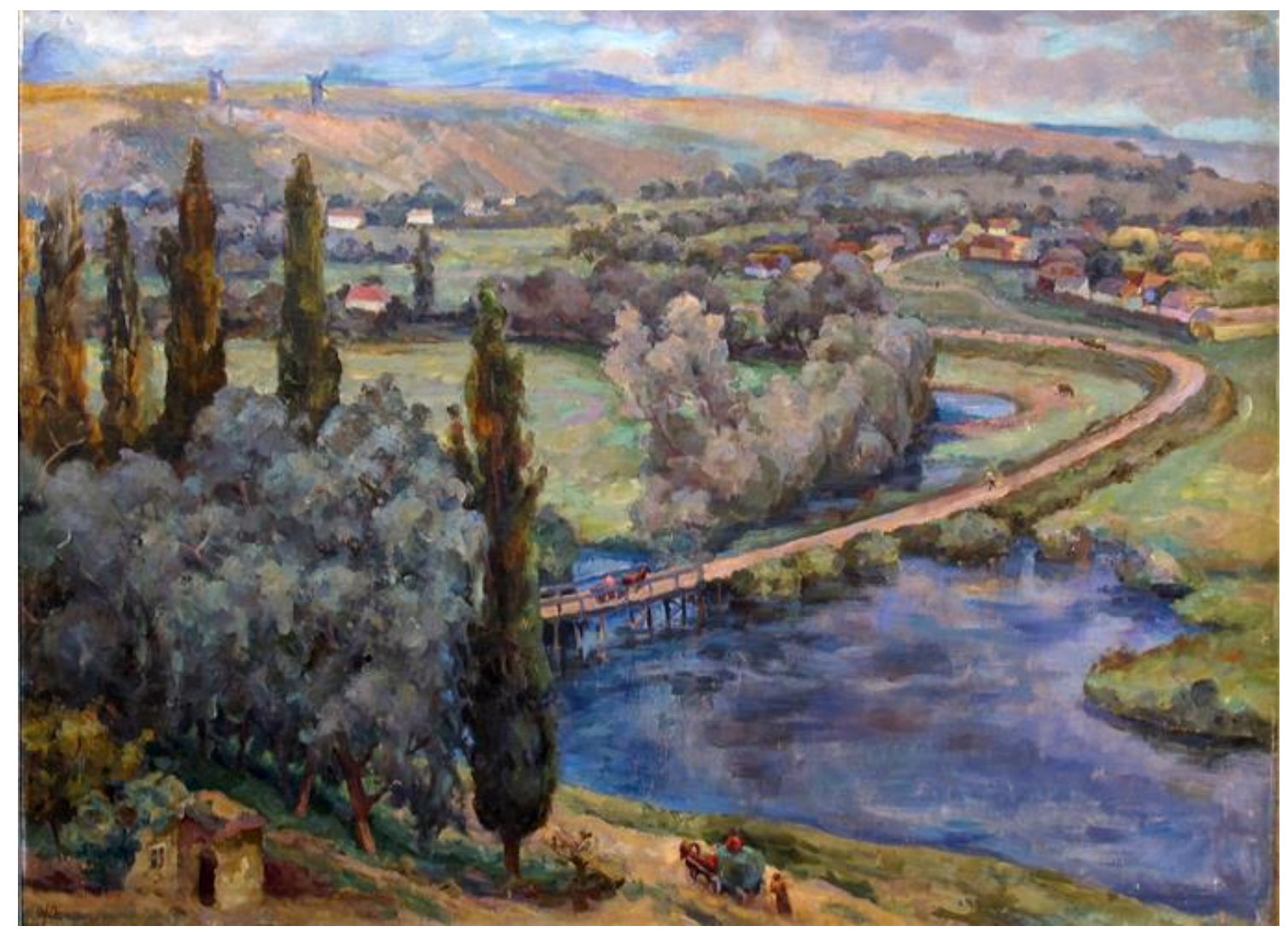

Painting 5: Alexander Osmerkin's, Ukraine, 1930; oil on canvas, $83 \times 115 \mathrm{~cm}$. Regional Art Museum, Kropyvnytskyi (photograph provided by Regional Art Museum).

Plastic expressiveness is still achieved with the help of light and color. The artist is capable to discover such unique techniques that most accurately convey the idea of the picture. These techniques are designed to reflect the current form of aesthetic expression, which is in demand of time. The horizon line in his composition comes close to the top edge of the picture, there are almost all shades of green that P. Cézanne used in his works. However, in his landscapes A. Osmerkin demonstrates dynamic compositions, the colored sky (which is almost invisible on the canvas) is reflected in the river, complementing the cool shades of greenery. The space is not transmitted by division to foreground and background, but through the artist's holistic coverage of the panoramic area and with the help of a thoughtful color solution. The expressiveness of the work is achieved by the fact that in consonant shades of green the artist carefully selects planes that should come to the forefront not at the expense of warm-coldness distinction, but at the expense of a color spot. He directs the movement of the viewer's gaze deep into the picture, in which a feeling of depth and volume is created by focusing on poplars standing along the front edge, a bright splash of blue tone in the river and emphasized road movement. The main thing for A. Osmerkin always remains the principle of expressiveness of painting in its "genuine plastic expression" (Nikich, 1981).

The artist is immersed in a kind of "quiet realism", which, against the background of the pompous, ceremonial stalinist social realism, is in charge of intimacy, lyrical and philosophical intonations. The painter is more concerned with the real simple things surrounding the person, as well as the real problems of the painting itself. During this period, A. Osmerkin was interested not only in the french artists, but also in the works of the XIX century Russian artist Alexander Ivanov. Numerous landscapes, "studies" of trees, which A. Ivanov created, became a key in the further development of landscape motifs for A. Osmerkin. Thus, the "Crimean landscape with poplars" (Painting 6), "Morning. Crimea. Goats" (1939; 33,5 × 44,5), "Pine" (late 1930s; $81 \times 71$ ) (all - canvas, oil; Osmerkin Museum) are the obvious steps towards nature, which the artist makes easily and joyfully, while simultaneously recalling the achievements of impressionism. It is enough to compare these works with the landscapes of the 1920s, where nature was often "hidden" behind the structure of the form. 
The "classical" planned construction of space is always emphasized in the works of the 1930s. The mountain relief of these landscapes dictates the painter a high point of view, which allows to capture the whole view in its integrity. The color variety is greatly enriched.

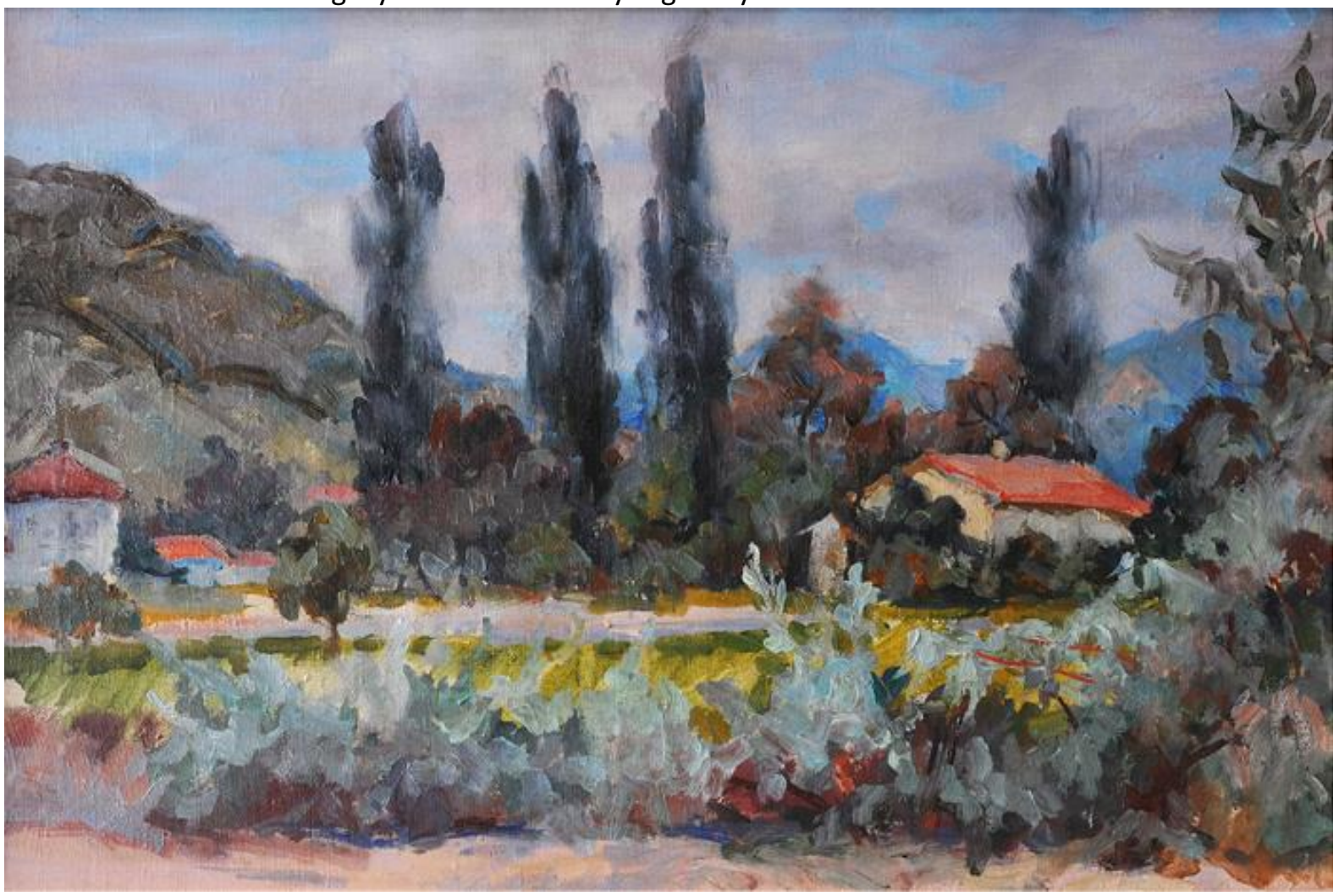

Painting 6: Alexander Osmerkin's, Crimean landscape with poplars, 1938, oil on canvas, $42,5 \times 64,5$ $\mathrm{cm}$. A. Osmerkin Art-Memorial Museum, Kropyvnytskyi (photograph provided by Osmerkin Museum, № XMMO-21).

Subsequently, the creative principles of A. Osmerkin will be formed into a certain system. The artist begins to teach first at the Vasily Surikov Art Institute in Moscow, then at the llya Repin Institute of Painting in Leningrad, working simultaneously in these two educational institutions. The master has always advised his students not to forget the classics and stressed that painting should be "beautiful, aesthetic and melodic", and this motto has repeatedly recalled his own passion with the works of Eugène Delacroix and Vasily Surikov (Nikich, 1981). In the works of any genre, the artist sought to achieve the level of the painting fullness. It is precisely classical phenomena - romanticism, realism in its many manifestations, and especially impressionism - that inspired A. Osmerkin to the optimistic palette he used.

The paintings of the 1940s demonstrate the highest level of the pictorial skill. The artist departs from the conscious austerity of early works and creates works filled with the joy of living in the unity with nature, the objective world and with each person who turns out to be an interesting model. During these years he painted portraits of people who are close to him, for example, in 1940, he worked on the image of the poet Anna Akhmatova, who was endowing him with special spirituality and poetry.

The portraits of this period, that are in the collection of the A. Osmerkin Art-Memorial Museum, show the artist's aspiration for subtle lyricism and the synthesis of a wide variety of pictorial systems in one picture. Such artwork, for example, is the "Portrait of M. B. Vinets" (Painting 7), that is built on the contrasts of the background color spots and the image of the model in a colorful dress. The painting style in which the portrait is made is directed to the channel of realism with a combination of impressionistic techniques. Compositionally, the portrait is reminiscent of the painting "A Woman in a Rocking Chairv" by Auguste Renoir (Chicago Institute of Art), and in a pictorial decision it approaches to some degree to the "Portrait of a Chorus Girl" by Konstantin Korovin (1887; 53,5 × 
41,2; canvas on cardboard, oil; Tretyakov Gallery). The background of the "Portrait of M. B. Vinets" is written in a wide free manner, the artist brings to the fore the heroine of the portrait, more thoroughly prescribing and working through both the face and the whole of her image. Her relaxed posture in the rocking chair only partly gives the impression of peace and tranquility, in fact, the expressive background is more active, sounding and enlivens the general character of the painting.

The artist's desire to give greater interpretation variety to the portrait image and even to go beyond the genre irritated official criticism. A. Osmerkin was attacked for the insignificance of the themes of his paintings, the illegality of equalizing the image of a person with the entourage or thing. The artwork "Profile and Flowers (In the Artist's Studio)" (1946; oil on canvas; $130 \times 100$; The Tretyakov Gallery), where the female image is equalized with a bunch of flowers in the background, was subjected to fierce criticism. Critics saw a reduction in the importance of the person depicted, a violation of all the laws of the genre and accused the artist of the portrait tasks misunderstanding.

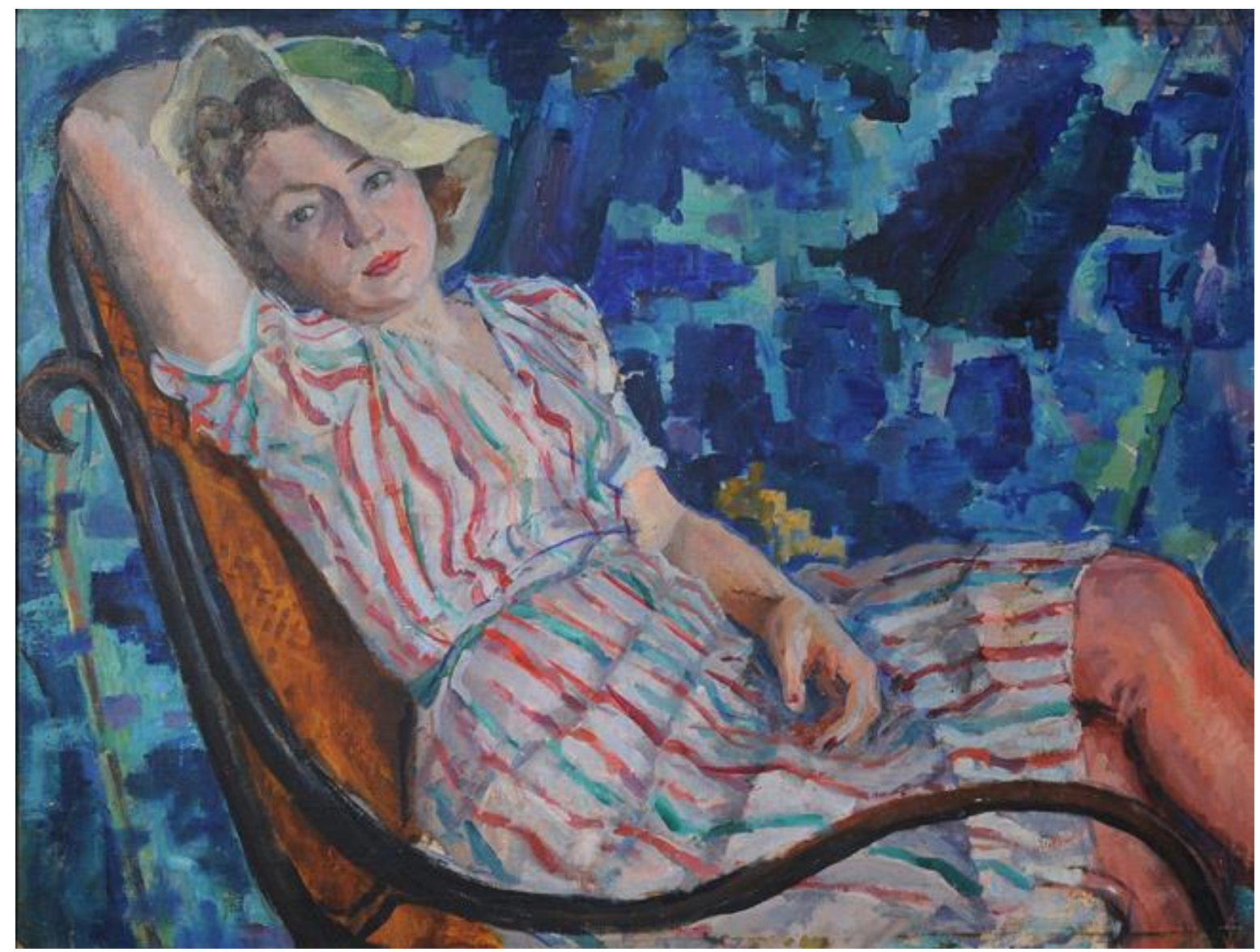

Painting 7: Alexander Osmerkin's, Portrait of M. B. Vinets, 1943-1944, oil on canvas, $70 \times 100 \mathrm{~cm}$.

A. Osmerkin Art-Memorial Museum, Kropyvnytskyi (photograph provided by Osmerkin Museum, № XMMO-16).

Changing preferences in his artistic orientations, A. Osmerkin remained faithful to the pictorial system he has worked out. The color in his canvases serves not to paint the plane, but to transfer volumes and activate space. All shades fit into a single palette, complementing each other. For example, each gradation of the picture "Vereya. Girls on the Terrace" (1941; $143 \times 123$; oil on canvas; Regional Art Museum) is not just lightening or darkening the main color, it is a search for a new, correct shade that forms the overall volume. Color expression, saturation of tone are in tune with the artist's early works. The color achievements, the ability to work in a certain way, the pictorial and plastic development of the whole plane of the picture, that were the key characteristic of the early works, are now combined with a more mature understanding of life. 
Objects are also important in A. Osmerkin's picture space. The artist to symbolize the world that surrounds the person, giving him the opportunity to reveal the artistic image more accurately and to fill the canvas with multidimensional picturesque plastisticity. Sometimes, with the help of an entourage, the artist clarifies the nature of the model's activity, as in "The Portrait of V. K. Yurkevich" (1948, oil on canvas; $121 \times 90$; Osmerkin Museum), depicting an architect surrounded by objects indicating his occupation. The painting "Green Coat (Portrait of N. G. Osmerkin)" (Painting 8) personifies that fullness with symbolic images that was characteristic of the artist's entire creative life. The title itself contains a code that allows one to guess the secret meaning of the work: we have a portrait of the artist's wife, who recuts a men's green coat. But the coat itself and the items that fill the room can be decoded as biographical signs that indicate certain life problems. The simplicity of the statement, its chamber nature is supported by a color palette. The contrast of colors in the picture does not cause tension, it is justified by all the selection of things and their semantic content, bringing to the forefront exactly the coat as a symbol of the author's presence in the space of the room. Intentionally creating the background in gray tones, the artist places the light in such a way that it does not create volume and shape, but color.

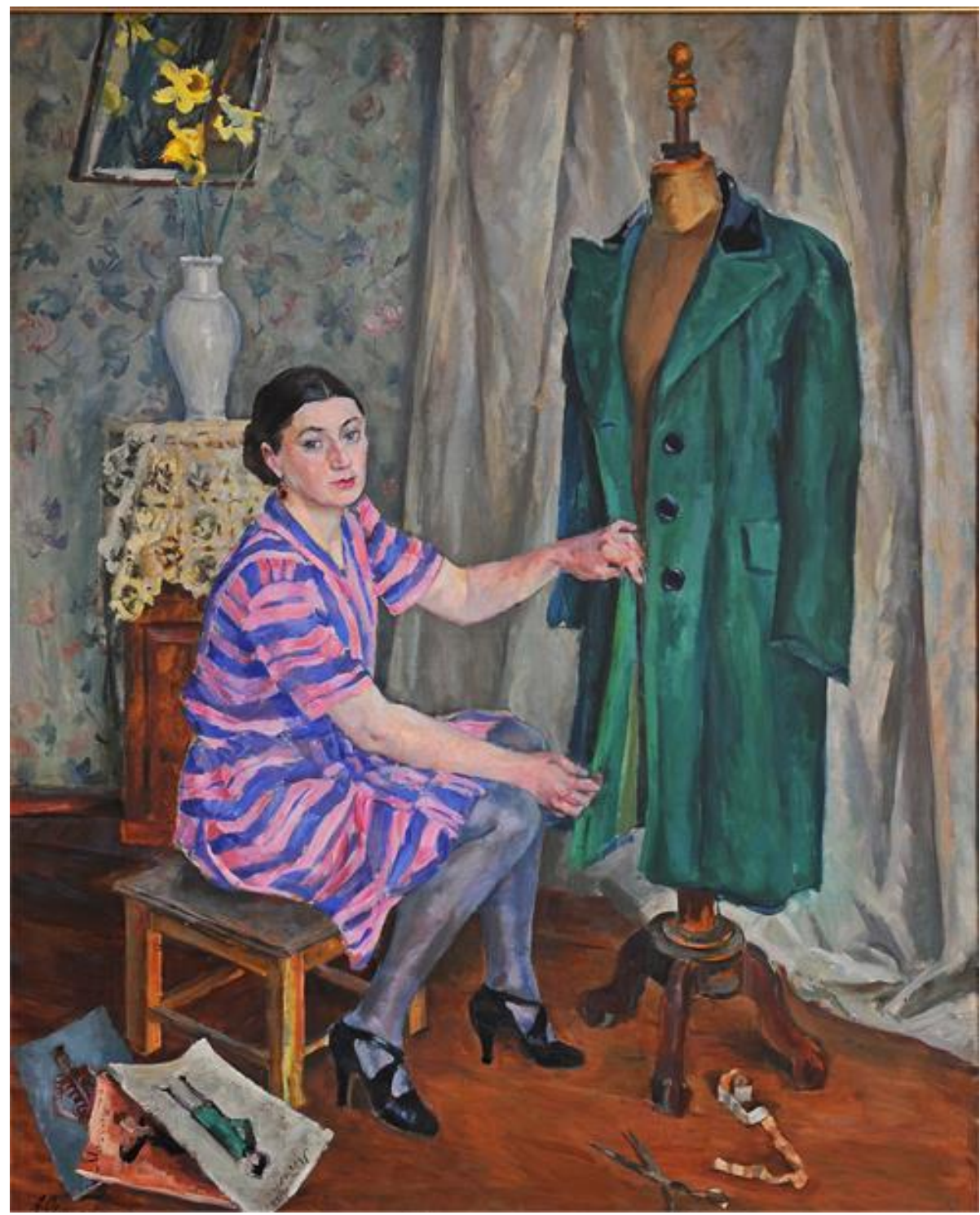

Painting 8: Alexander Osmerkin's, Green Coat (Portrait of N. G. Osmerkin), 1947, oil on canvas, $159 \times$ $129 \mathrm{~cm}$. A. Osmerkin Art-Memorial Museum, Kropyvnytskyi (photograph provided by Osmerkin Museum, № XMMO-1269). 
The space of things in still lives of this period slightly changes. For example, the paintings "'Astoria", number 103" (1945; oil on canvas; $120 \times 76,5$; Osmerkin Museum; paint. 7), "Still life. Blackberry pie" (oil on canvas; $80 \times 90$ ), "Still Life with a Vinaigrette" (oil on canvas; $87 \times 98$ ) - (both 1948; the Regional Art Museum) demonstrate the artist's passion for combining and matching the plasticity of objects in space. In one case, it is intended to convey a joyful, high spirits, in the other one - the subject line creates an atmosphere of intimacy and a home coziness. The space in the "'Astoria", number 103" is created by the imposition of planes, meaning that object is superimposed on another one. Such a system of imposing elements on each other can be found in the icon painting. Probably, the appearance of iconographic techniques in A. Osmerkin's painting can be attributed to the fact that he could observe the work of icon painters during his childhood and youth, since his uncle Yakov Pauchenko's own icon-painting workshop was in the courtyard of his house. Observation of the work of icon painters and insight into the specifics of the image of the objective world in the icons left their imprint, which eventually manifested itself in the unique style of the artist. The influence of French impressionism and post-impressionism is visible in the painting itself, but at the same time A. Osmerkin brings some of his own intonations to enliven the composition. He interprets the content of the work in such a way that it would be clear to the viewer that the picture has a plot, all the objects matter and they can "explain" the reasons for their appearance here. In general, all the works of A. Osmerkin are permeated with plot and a certain desire for theatricality.

So, having considered the peculiarities of A. Osmerkin's work in the period of the 1930s - 1940s, it can be noted that the artist under the influence of the political situation in the country, is forced to turn to realistic reproduction of the world, while not fitting into the general trend of socialistic realism. By the nature of his work, his chamber works can be rather referred to as "quiet realism". A. Osmerkin remains faithful to the principles of high pictorial culture, skillfully synthesizes in one composition techniques of romanticism, impressionism, post-impressionism and realism, which greatly enriches the plastic expressiveness of his painting.

The last period of the life and work of A. Osmerkin is filled with tragedy. After a new wave of accusations of "formalism", the artist is suspended from teaching and is forced to turn to the execution of the official order for the group portrait "Lead workers at the Stalin Automobile Plant" (sketch - 1949; 51 × 69; oil on cardboard; Osmerkin Museum). The finished picture "Lead workers at the Stalin Automobile Plant" is in a private collection and in 2014 was put up for sale in one of the Russian auction houses (SOVKOM Gallery, Moscow). Earlier, the artist complained that he couldn't obtain large thematic paintings, and he could not grasp the sense of time to respond to it with a grandiose plot canvas. The government provided him with the "opportunity" to rehabilitate and create work that would meet the needs of the time, if not a genre picture, but at least a portrait of the foremost production. Work on the order was painful, as it was accompanied by the supervision of an employee of the NKVD (People's Commissariat of Internal Affairs of the USSR), who lived in the same apartment with the artist and not only watched the execution of the official order, but was constantly present in the private life of the family. All of these hurt the soul of the artist, caused a lot of inconvenience and undermined the health of A. Osmerkin. In an effort to meet the requirements of the Soviet ideology in thematic terms, the artist solves all the same painterly tasks in his work and seeks expressive form and color. The work was not accepted by the commission, moreover, a case of some financial embezzlement was instituted against A. Osmerkin, but was closed in a while.

The result of the persecution was a serious illness. However, the artist tried to overcome the hardships that had befallen him, and till the last days he worked in his studio, trying to preserve the beauty of painting and the lyricism of the images created. This can be seen in the works of the latest years from the collection of the Osmerkin Museum. In the portrait "Katyusha" (1953, oil on canvas; $56 \times 56)$ the weakened hand of the master is already felt, but he rather confidently sculpts the 
model's face. In the 1951 "Self-Portrait" (cardboard, oil; $70 \times 50$ ), in the last unfinished landscape "Pleskovo" (cardboard, oil; $87 \times 67$ ) there is ease of performance, the images are endowed with a bright lyrical mood. Density disappears from the painting, the coloring is lightened, and a sketch of a drawing appears. The quest path has ended. Having lived a rich creative life, A. Osmerkin remained faithful to his aesthetic creed that has found fertile ground, being revealed in the works of his students.

\section{Conclusion}

Summing up, it should be noted that the creative search of Alexander Osmerkin was carried out in the direction of the plastic expressiveness of the painting. Revealing the aesthetic positions of the artist at early and mature stages of creativity allows us to conclude that the artist paid great attention to the plasticity of color, by the help of which he built form and space, without taking the color composition from the task of the image. Being a follower of P. Cezanne in his early work, A. Osmerkin called decorative effect an essential quality of art, which he understood primarily as a means of organizing color. Examination of the figuratively-stylistic features of the artist's works showed that he was attracted to painting not by its own beauty, but by its harmoniously constructed color, which conveys the beauty of nature in its individual state through the color ratio. In the postrevolutionary time, when many representatives of the avant-garde movements were forced to abandon the radical transformations of form and space in the picture, A. Osmerkin became a consistent realist, who, however, was not so much interested in the plot as the solution of plastic problems by means of impressionistic painting. At this stage, the artist strives for pictures in the most "non-painting" genres - in still life, landscape, portrait, working in a peculiar style of "quiet realism". In the last years of his work A. Osmerkin, with unprecedented before freedom, introduces bright multicolor into his canvases. His compositions, as before, are organized with the help of expressiveness of color; there is free and at the same time thoughtfully strict pictoriality in relations with nature are in his canvases. A comprehensive analysis of A. Osmerkin's aesthetic views reveals their reflection in his picture of the world; a sublime attitude to the reality surrounding him, a sense of harmony of nature and hidden poetry of simple things, breathed beauty into his works, which inspired both his contemporaries and artists of a later time. In future, the study of the educational activity of A. Osmerkin, consideration of his pedagogical system and its influence on the creative formation of students will become productive.

\section{References}

Adorno, T. W. (1995). Ästhetische Theorie. Hrsg. von Gretel Adorno und Rolf Tiedemann. 13. Aufl. Frankfurt am Main: Suhrkamp [in German].

Akimova, L. (1960). Tvorchestvo A. A. Osmerkina [The work of A. A. Osmerkin]. Moscow: Iskusstvo [in Russian].

Bolotina, I. \& Shcherbakov, A. (1989). Aleksandr Aleksandrovich Osmerkin, 1892-1953: Zhivopis, grafika, teatr: Katalog [Alexander Osmerkin, 1892-1953: Painting, graphics, theater: Catalog]. Moscow: Sov. hudozhnik [in Russian].

Deyneka, A. (1959). Tvorcheskaya zhizn. Vyistavka A. Osmerkina [Creative life. Exhibition of A. Osmerkin]. Tvorchestvo - Creation, 12, 14. [in Russian].

Gadamer, H. G. (1960). Wahrheit und Methode. Tübingen [in German]. 
Kagan, M. S. (1997). Estetika kak filosofskaya nauka [Aesthetics as a philosophical science]. SanktPeterburg, TOO TK "Petropolis" [in Russian].

Kostenevich, A. G. (Eds.) (1998). Pol Sezann i russkiy avangard nachala XX veka: Katalog vyistavki [Paul Cezanne and the Russian avant-garde of the early twentieth century: Exhibition catalog]. SPb: Slaviya [in Russian].

Krivtsun, O. A. (2018). Plasticheskoe myishlenie $v$ iskusstve: linii vliyaniya [Plastic thinking in art: lines of influence]. Artikult. Nauchnyiy elektronnyiy zhurnal - ARTICLE. Scientific electronic journal, 26, 2034. DOI: 10.28995/2227-6165-2018-1-20-34 [in Russian].

Malkova, O. P. (2006). Tvorchestvo hudozhnikov «Bubnovogo valeta» vtoroy polovinyi 1910-1950. Sotsiokulturnyie i plasticheskie aspektyi (na materiale sobraniya Volgogradskogo muzeya izobrazitelnyih iskusstv) [Creative works of artists of the "Bubble valley" of the second half of 19101950. Socio-cultural and plastic aspects (based on the collection of the Volgograd Museum of Fine Arts)]. Extended abstract of candidate's thesis. Sankt-Peterburg: Rossiyskaya Akademiya hudozhestv [in Russian].

Melikadze, E., \& Syisoev, P. (1939). Sovetskaya zhivopis. Kratkie biografii hudozhnikov i reproduktsii kartin [Soviet painting. Brief biographies of artists and reproductions of paintings]. Moscow: Iskusstvo [in Russian].

Morozov, A. I. (1995). Konets utopii. Iz istorii iskusstva v SSSR 1930-h godov [The end of utopia. From the History of Art in the USSR in the 1930s]. Moscow: Galart [in Russian].

Nadezhdin, A. (2004). Don Kihot iz ukrainskoy stepi [Don Quixote from the Ukrainian steppe]. Retrieved from http://www.osmerkinmuseum.kr.ua/apub/pub14_r.html [in Russian].

Nadezhdin, A. (2007). Poetyka Peizazhu v tvorchosti Oleksandra Osmorkina [Poetics of landscape in the works of Alexander Osmerkin]. Retrieved from http://osmerkinmuseum.kr.ua/apub/pub01.html [in Ukrainian]

Nikich, A. Yu. (Eds.) (1981). Osmerkin. Razmyishleniya ob iskusstve. Pisma. Kritika. Vospominaniya sovremennikov [Osmerkin. Reflections on art. Letters. Criticism. Memoirs of Contemporaries]. Moscow: Sovetskiy hudozhnik [in Russian].

Pospelov, G. G. (1990). "Bubnovyiy valet": Primitiv i gorodskoy folklor v moskovskoy zhivopisi 1910-h godov ["Jack of Diamonds": Primitive and Urban Folklore in Moscow Painting]. Moscow: Sovetskiy hudozhnik [in Russian].

Svetlyakov, K. A. (2002). Problema zhivopisnoy realizatsii Polya Sezanna i traditsiya russkogo sezannizma pervoy polovinyi XX veka [The problem of the picturesque implementation of Paul Cezanne and the tradition of Russian seasonism of the first half of the XX century]. Extended abstract of candidate's thesis. Moscow: MGU im. M. Lomonosova [in Russian].

Turchinskaya, E. Yu. (2013). Sezannizm i otechestvennaya zhivopis XX veka [Cezannism and Russian painting of the 20th century]. Nauchnyie trudyi (Sankt-Peterburgskiy gosudarstvennyiy akademicheskiy institut zhivopisi, skulpturyi i arhitekturyi imeni I. E. Repina) - Scientific works (St. Petersburg State Academic Institute of Painting, Sculpture and Architecture named after I. E. Repin, 24. Retrieved from http://www.gup.ru/events/smi/detail.php?ID=165986 [in Russian].

Usoltseva, L. I. (1973). Aleksandr Osmerkin. 1892-1953. [Alexander Osmerkin. 1892-1953]. Leningrad: Hudozhnik RSFSR [in Russian]. 